\title{
Intense removal and non-saturating functional responses by recreational divers on spiny lobster Panulirus argus
}

\author{
David B. Eggleston ${ }^{1, *}$, Eric G. Johnson ${ }^{1}$, G. Todd Kellison ${ }^{1,2}$, David A. Nadeau ${ }^{1}$ \\ ${ }^{1}$ North Carolina State University, Department of Marine, Earth and Atmospheric Sciences, Raleigh, \\ North Carolina 27695-8208, USA \\ ${ }^{2}$ Present address: Biscayne National Park, 9700 SW 328th Street, Homestead, Florida 33033, USA
}

\begin{abstract}
The effects of recreational fishing often go undetected, yet can lead to the collapse of fishery populations. Fishery managers must understand the dynamics of recreational fishers and their prey to successfully predict the outcome of management actions. We measured the impact of a $2 \mathrm{~d}$ exclusively recreational fishery on the Caribbean spiny lobster Panulirus argus in the Florida Keys, USA, and used a theoretical, predator-prey functional response approach to identify whether or not sport diver catch rates were density-independent or -dependent (Types I, II or III functional response), and if catch rates were saturated (i.e. reached an asymptote) at relatively high lobster densities. Herein, we describe how this predator-prey framework could be applied to fisheries management for the spiny lobster. Our approach consisted of SCUBA diver surveys of lobster distribution and abundance patterns immediately before and after the $2 \mathrm{~d}$ recreational 'mini-season' coupled with counts of recreational boats and divers to assess the aggregative response of divers to lobster density. During the mini-season, the density of boats along coral patch reefs and patch heads was over $900 \times$ higher than during the regular fishing season $~ 3$ wk later. Overall, there was a 95 and $79 \%$ decline in mean lobster densities in the patch reef and patch head habitats, respectively. Fishing effort was $10 \times$ greater on patch heads than on reefs, probably due to 100 -fold higher lobster densities in patch-head habitats. In both patch reefs and heads, the proportion of lobsters removed by divers was density-independent (Type I functional response). Diver catch never reached saturation at natural lobster densities. Thus, recreational divers have a relatively simple predatory response to spiny lobsters, whereby catch rates increase linearly with lobster density such that catch is a reliable indicator of abundance. A major concern is that the current levels of lobster exploitation by sport divers are extremely high $(\sim 90 \%)$; however, diver predation pressure is not expected to increase proportionally with a decline in lobster density, which could exacerbate local extinction. Management actions that reduce diver effort should have a concomitant reduction in catch. The recreational diver-lobster predator-prey construct in this study provides a useful predictive framework on which to build as the spatiotemporal scales of measurements expand, management actions are implemented, and the lobster population varies.
\end{abstract}

KEY WORDS: Caribbean spiny lobster $\cdot$ Density-independence $\cdot$ Fishery management $\cdot$ Recreational fishing impacts $\cdot$ Florida Keys $\cdot$ Functional response $\cdot$ Maximum likelihood · Overfishing $\cdot$ Predator-prey theory

Resale or republication not permitted without written consent of the publisher -

\section{INTRODUCTION}

There is growing concern about the seemingly insidious effects of recreational fishing on fishery populations. Recreational fisheries are typically viewed differently from commercial fisheries in that economic incentives to overexploit populations are lacking (Post et al. 2002), yet recreational fishing can produce strong direct and indirect effects in aquatic ecosystems (Magnuson 1991, Kitchell 1992, Kitchell \& Carpenter 1993, 
Post et al. 2002), and has led to severe declines in marine fishes such as red drum Scianops ocellatus (Vaughan \& Carmichael 2000) and intense reductions in local populations of the abalone Haliotis sp. in central California, USA (Haaker et al. 1996), and in the Caribbean spiny lobster Panulirus argus in the Florida Keys, USA (Eggleston \& Dahlgren 2001). Recreational fishermen are opportunistic, and often use sophisticated equipment and up-to-date information to respond to changes in distribution and abundance patterns of their quarry in a manner similar to natural predator-prey systems (Carpenter et al. 1994, Johnson \& Carpenter 1994, Post et al. 2002). To prevent the widespread collapse of recreational fisheries and successfully predict the outcome of management actions, fishery scientists and managers must understand the dynamics of recreational fishermen-prey interactions, such as the functional relationship between fishing effort, prey capture, and prey density.

\section{Spiny lobster biology and fishery}

The Caribbean spiny lobster Panulirus argus supports important commercial fisheries throughout most of its range, from Bermuda to Brazil. Caribbean spiny lobsters enter shallow nearshore waters as postlarvae from the open ocean, and reach a legally harvestable size of $76 \mathrm{~mm}$ carapace length (CL) approximately $2 \mathrm{yr}$ after settlement (Forcucci et al. 1994, Butler \& Herrnkind 2000). Caribbean spiny lobsters are highly gregarious, aggregating in crevices and beneath sponges during the day (Eggleston \& Lipcius 1992, Eggleston \& Dahlgren 2001), and foraging on gastropods, chitons and bivalves in nearby seagrass beds and hard-bottom habitats at night (Cox et al. 1997). Although there is a general ontogenetic migration of lobsters from inshore nursery habitats to offshore reefs as they mature (Davis \& Dodrill 1989), the fishery targets lobsters across a continuum of inshore and offshore areas. The commercial fishery in Florida, USA, targets the gregarious behavior of spiny lobsters by using traps baited with sublegal-sized lobsters as attractants (Hunt et al. 1986), and the recreational fishery targets primarily aggregations of lobsters in crevices during the day. During the late 1970s and 1980s, the trap fishery in Florida increased sharply without a concomitant increase in landings (Hunt 2000). The size-structure of the trappable population has also shifted toward an increasing proportion of smaller lobsters (Lyons et al. 1981). Consequently, the commercial fishery relies almost exclusively on new recruitment of legal-sized lobsters in each fishing year (Powers \& Sutherland 1989). Recruitment of postlarval spiny lobster to the Florida Keys is probably heavily dependent on upstream, pan-
Caribbean sources of larvae, since the mitochondrial genomes of $P$. argus collected from 5 locales in the Caribbean indicated no restrictions to gene flow (Silberman et al. 1994). The spiny lobster fishery in Florida is overcapitalized (Lyons 1986), and a trap-reduction program was implemented in August 1993 to reduce excess effort in the Keys spiny lobster fishery. Lobster landings are predicted to remain cyclically stable as the number of traps decrease (Hunt 2000).

The spiny lobster fishing season is closed during the peak spawning period between March and July. Each year, approximately 50000 people don SCUBA and snorkeling gear to catch Caribbean spiny lobster in Florida during a special $2 \mathrm{~d}$ sport season that is open in July just prior to the opening of the regular lobster season on August 1 to both recreational and commercial fishers. In an attempt to relieve the increasing conflict between commercial and recreational lobster fishers, the Florida legislature enacted a bill in 1975 that established a special $2 \mathrm{~d}$ recreational season on spiny lobsters that was scheduled $1 \mathrm{wk}$ prior to the opening of the commercial fishing season (Labisky et al. 1980). Divers typically use a 'tickle stick' to coerce lobsters from their dens into a hand-held fishing net. The daily limit is 6 lobsters person ${ }^{-1} \mathrm{~d}^{-1}$ in Monroe County (Florida Keys), and divers must possess a recreational salt water fishing license and a special lobster stamp for the $2 \mathrm{~d}$ mini-season. The recreational harvest accounts for $41 \%$ of the total lobster landings in August each year, and $22 \%$ of the total annual harvest (Hunt 2000). In 2001, a total of $25 \%$ of the annual recreational fishing effort for spiny lobster was expended during the $2 \mathrm{~d}$ mini-season in Florida (Leeworthy 2002). The majority of the overall recreational fishing effort is concentrated in the Florida Keys (Monroe County), which accounts for $60 \%$ of the statewide effort (Florida Fish \& Wildlife 2002).

The socio-economic impact of the $2 \mathrm{~d}$ mini-season in Monroe County is significant, having contributed approximately $\$ 7$ million to the local economy in 2001 (Leeworthy 2002), with $95 \%$ of the economic impact due to visitors to Monroe County (Leeworthy 2002). During several weeks preceding the mini-season, an increasing number of boaters can be seen towing divers in shallow water searching for aggregations of lobsters and marking the locations of lobsters with GPS units (D. B. Eggleston pers. obs.). This recreational diver reconnaissance for lobsters in 2002 was most apparent over continuous patch reef and patch coralhead habitats, beneath bridges, and in channels.

On the opening day of the mini-season, a parade of boats leave shore-based boat ramps, docks and marinas and anchor at lobstering sites before dawn. This ritual has occurred for decades. Of concern to fishery managers is the apparently increasing use of recre- 
ational and commercial diving to harvest lobsters at the same time as mandatory trap reductions are implemented in the commercial sector of the fishery. Increasing use of diving makes management difficult, since the primary way of managing the fishery is through trap effort (J. Hunt, Florida Fish \& Wildlife, pers. comm.). Moreover, recent data indicate that the 2 d mini-season has a highly significant impact on spiny lobsters in areas that are both open and closed to fishing (i.e. marine protected areas), resulting in an $80 \%$ reduction in the local population off Key West, Florida, in just 2 d (Eggleston \& Dahlgren 2001).

The overall goal of this study was to measure the impact of the recreational $2 \mathrm{~d}$ fishing season on the local population of Caribbean spiny lobsters in the Great White Heron National Wildlife Refuge (GWHNWR), Florida Keys, USA, and to apply predator-prey theory to understand the behavioral response of divers to varying lobster densities, and thereby predict the effects of management on catch.

\section{Application of predator-prey theory}

The interactions between fishermen, their prey and management actions can be complex. The functional response, which is the relationship between the consumption rate of a predator and the density of its prey, provides a powerful theoretical framework to predict the outcome of fishery management actions on the dynamic relationship between recreational fishers and their prey (Hilborn \& Walters 1992, Carpenter et al. 1994, Johnson \& Carpenter 1994, Post et al. 2002). Functional responses are generally thought to have 3 basic forms, although this traditional typology may be inadequate under some natural situations (Abrams 1982). The simplest form is a predator whose pattern of searching is random and whose rate of searching remains constant at all prey densities, leading to a Type I functional response, where $N_{\mathrm{e}}=N_{0}\left\{1-\exp \left(-a^{\prime} \cdot T\right)\right\}$. In this case, the number of prey encountered $\left(N_{\mathrm{e}}\right)$ is equal to the product of the prey density $\left(N_{0}\right)$ and the exponent of the product of the instantaneous attack rate $\left(a^{\prime}\right)$ and period of observation ( $T$ ). In a Type I functional response, the linear increase in consumption rates with prey density abruptly reaches an asymptote where the predator becomes saturated; the relationship between proportional mortality and prey density is density-independent (Holling 1966). Non-saturating functional responses have been reported for zooplankton (Huntley 1981 and references therein) and are considered a form of Type I functional response. The implication of an unsaturated Type I functional response to fisheries management is that a reduction in harvest levels, such as reductions in the length of the fishing season or in catch limits, would lead to a linear reduction in catch. The application of a Type I functional response to fisheries management is further expanded in the discussion section of this paper.

A hyperbolic, Type II functional response rises at a continuously decreasing rate to an upper asymptote and is inversely density-dependent (Hassell 1978). A Type III functional response is sigmoid, demonstrating density-dependent acceleration in feeding rates at low to moderate prey densities. The key difference between Types II and III responses is that in a Type II functional response, proportional mortality rates increase with decreasing prey density (i.e. depensatory mortality), which is destabilizing to predator-prey dynamics, whereas in a Type III response, proportional mortality rates decrease with decreasing prey density (i.e. compensatory mortality), which is stabilizing to predator-prey dynamics (Hassell 1978, Lipcius \& Hines 1986, Murdoch \& Bence 1987, Eggleston et al. 1992, Seitz et al. 2001 and references therein). A Type I functional response could be considered partially stabilizing to predator-prey dynamics relative to a Type II response.

In this paper, we apply the functional response framework to recreational divers harvesting Caribbean spiny lobsters in the Florida Keys during a 2 d, exclusively recreational fishing season. Our approach used SCUBA diver surveys of lobster distribution and abundance patterns before and after the $2 \mathrm{~d}$ fishing season, coupled with counts of recreational diver effort at each sampling location. Linear and non-linear regression models, ANOVA, and maximum likelihood approaches were then used to assess the form (i.e. Types I, II, III) of diver-lobster functional responses. An important feature emerging from our work is that management actions that reduce diver effort should result in a proportional decrease in lobster catch rates due to the non-saturating, linear nature of diver functional responses.

\section{MATERIALS AND METHODS}

Study sites. The Great White Heron National Wildlife Refuge (GWHNWR) is a somewhat rectangularshaped area of $784 \mathrm{~km}^{2}$ located on the north side of the lower Florida Keys in the Gulf of Mexico, extending west of Marathon Key to the western end of Key West (Fig. 1). The GWHNWR was established in 1938 to protect migratory birds such as herons and egrets that were decimated during the plume and meat trade in the early 1900s. Both commercial and recreational fishing is allowed within the majority of the GWHNWR. Marine habitats within the GWHNWR include mangrove, seagrass beds, macroalgal beds, sand flats and 


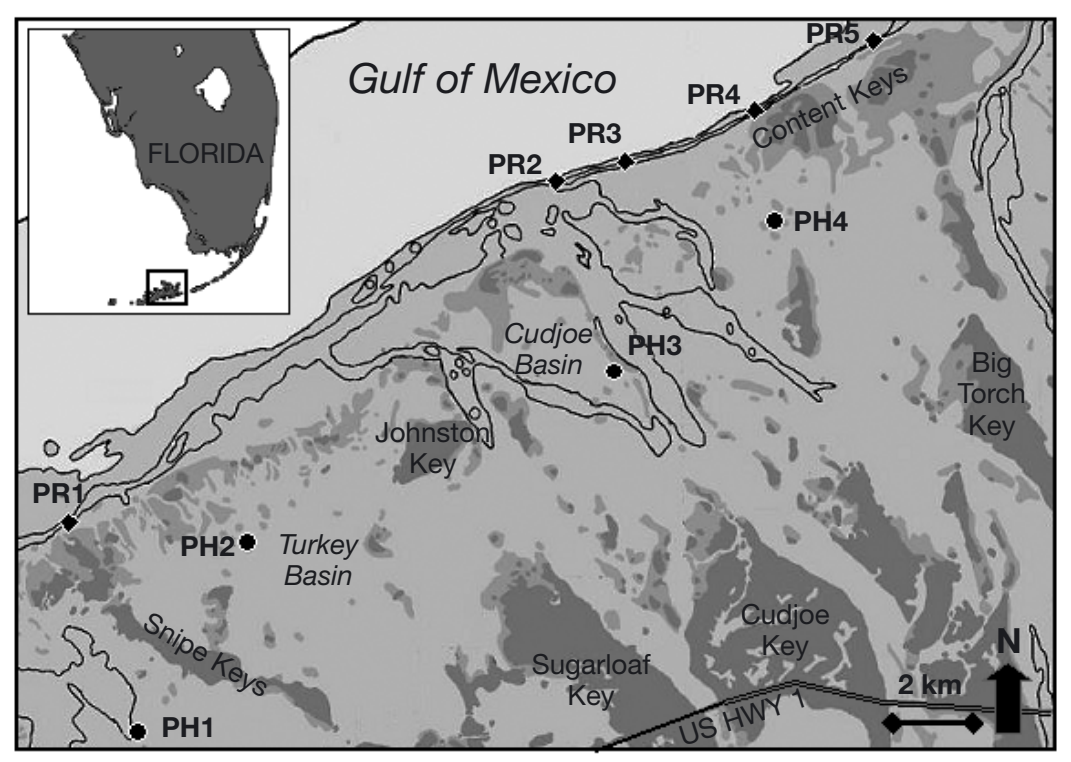

Fig. 1. Sampling sites between Snipe Keys to the southwest and Content Keys to the northwest and a line running east/west approx. $5 \mathrm{~km}$ north of US Highway 1 (US HWY 1) within Great White Heron National Wildlife Refuge (GWHNWR), Florida, USA. Alphanumerics PR and PH refer to continuous patch-reef and patch-head sampling sites, respectively; dark-gray areas: mangrove islands; light-gray areas: intertidal seagrass flats; contour lines: $5 \mathrm{~m}$ water depth

southwest and Content Keys to the northeast (Fig. 1). Lobsters were surveyed at all locations during a $2 \mathrm{~d}$ period immediately before and after the lobster mini-season. All surveys were conducted during the day (09:00 to 16:00 h), when water visibility exceeded $6 \mathrm{~m}$. Spiny lobster CL in $\mathrm{cm}$ was estimated by comparing a lobster with a ruler attached perpendicularly to the far end of a $70 \mathrm{~cm}$ rod held out by a diver (Eggleston \& Dahlgren 2001). This device helped avoid underwater magnification problems in estimating lobster sizes and aided in delineating the width of a transect at patch reefs (see next paragraph). Lobster CL was estimated to the nearest $1 \mathrm{~cm}$.

To sample lobsters in patch reefs, we superimposed a grid system containing cells measuring $2 \times 2 \mathrm{~km}$ over the reef from Content Keys to Snipe Keys (Fig. 1), and then randomly chose 5 of 10 cells to survey lobsters. At each patch-reef location, the research boat was anchored as close as possible to the

coral reefs. Coral reefs consist of 2 general types: continuous coral reefs and ledges (hereafter referred to as patch reefs), and patch-head reefs (hereafter referred to as patch heads). Patch reefs are generally located along the northeast by southwest axis of the northern margin of the GWHNWR between inshore, shallow flats that are bisected by channels and the Gulf of Mexico (Fig. 1). Patch-reef habitats consist of a thin veneer of sand overlying low-relief rock and exposed rock containing gorgonians, patch coral heads, sponges, and ledges of $0.5 \mathrm{~m}$ to $1 \mathrm{~m}$ relief. Patch heads consist of discrete aggregations of dome-shaped and circular corals such as Siderastrea siderea, Colpophyllia natans, and Montastraea annularis, which are located in shallow seagrass beds some distance from the shoreline. Patch heads generally range from 1 to $3 \mathrm{~m}$ in diameter. We quantified the impact of the recreational $2 \mathrm{~d}$ mini-season on spiny lobsters in areas containing patch reefs and heads (Fig. 1). According to local fishing guides, dive operators, and fisheries managers, the areas between Content and Snipe Keys (Fig. 1) consistently harbor the highest concentration of legal-sized spiny lobster and receive the greatest fishing pressure from recreational divers in the GWHNWR.

Lobster surveys. Visual survey techniques were used to quantify the distribution, abundance, and sizestructure of spiny lobsters at 5 patch-reef locations and 4 patch-head locations between Snipe Keys to the middle of a grid cell using a differential GPS, and 4 divers surveyed areas that were $90^{\circ}$ in the opposite direction from each other. Each diver swam in the same direction before and after the fishing season, so that observations could be paired for subsequent statistical analyses (see later subsection). Divers searched along an almost straight line away from the boat for 10 min, after which they surfaced and visually estimated the distance traveled from the boat. Area searched averaged $369 \mathrm{~m}^{-2}(\mathrm{SE}=50.1, \mathrm{n}=39)$. In a related study (Eggleston et al. in press), we assessed the accuracy of visual estimates of distance traveled and area searched during 10 min surveys, and found that although divers tended to overestimate the distance traveled by an average of $4.5 \mathrm{~m}$, estimates were not significantly different from known distances as measured with a differential GPS on a research boat (Eggleston et al. in press). The response variable for patch reefs was the density of spiny lobsters (no. $\mathrm{m}^{-2}$ ).

We used a directed approach to survey patch heads rather than randomly choosing patch-head locations, due to the clumped and somewhat limited nature of their distribution. In this case, we used a combination of nautical charts, local lobster fishing guides, and our own reconnaissance to identify major clusters of patch heads located in backreef areas between Content and Snipe Keys (Fig. 1). We identified 4 locations with patch heads, each harboring an average of 4 distinct patch heads that were visible from the boat and located in 
shallow water $(2 \mathrm{~m})$. Divers surveyed patch heads for lobsters as described above for patch reefs; however, the entire patch head was surveyed rather than using a transect approach. The mean area searched for each patch head was $7.33 \mathrm{~m}^{2}(\mathrm{SE}=2.43, \mathrm{n}=14)$. Initially, to express lobster density as a function of patch head volume, we estimated the volume of each patch-head by measuring (in $\mathrm{cm}$ ) the radius (r) and height of each head with a ruler and multiplying height by $\pi \mathrm{r}^{2}$. Subsequent statistical analyses indicated no significant relationship between the volume of a patch head and the number of lobsters (linear least-squares regression: $F=0.02, \mathrm{df}=1,28, \mathrm{p}=0.88$ ). Therefore, we used the density of spiny lobster (no. $\mathrm{m}^{-2}$ ) as a response variable for patch heads to allow comparisons with patch reefs. Each patch head was relocated after the mini-season using differential GPS coordinates.

Recreational diver surveys. To estimate recreational diver predation-pressure, we counted the number of dive boats anchored at each of our lobster survey locations, and estimated the number of divers per boat during both days of the $2 \mathrm{~d}$ mini-season. To place overall recreational diver effort during the mini-season into a broader spatial context, we also counted the number of dive boats along a band-transect encompassing a $26 \mathrm{~km}$ long (east/west axis) by $2 \mathrm{~km}$ wide (north/south axis) tract of continuous patch reef from Content Keys to Jewfish Channel on each day of the $2 \mathrm{~d}$ mini-season. Jewfish Channel is located $5.5 \mathrm{~km}$ southwest of Snipe Keys (Fig. 1). We also counted the numbers of dive boats along this same tract on 2 separate occasions approximately $3 \mathrm{wk}$ after the close of the mini-season and during the regular lobster-fishing season.

Statistical analyses. The density of legal-sized spiny lobsters (>7.6 cm CL) was compared between locations and over time with a 1-way repeated-measures ANOVA model; time (pre- vs post-fishing season) was the repeated measure and location was the factor. Two separate repeated-measures ANOVA models were analyzed for patch reefs (PR1 to PR5) and patch heads (PH1 to PH4: Fig. 1). Densities were $\log (x+1)$ transformed when necessary to meet assumptions of normality and homogeneity of variance. In one case, variances remained heteroscedastic despite several transformations (logarithm and square root). Thus, hypotheses regarding changes in lobster density were rejected at alpha values lower than the p-value of the test for homogeneity of variance (Underwood 1981). We then examined the relationship between fishing effort (divers $\mathrm{m}^{-2}$ ) and the density of lobsters (no. $\mathrm{m}^{-2}$ ) 1 to $2 \mathrm{~d}$ prior to the fishing season with both linear and non-linear regression models.

Our goal concerning the functional response of recreational divers to spiny lobsters was to determine if removal rates (fishing mortality rates) were density- independent or -dependent and, if density-dependent, whether the functional response was potentially stabilizing (Type III) or destabilizing (Type II) to lobster population dynamics. We used 2 approaches to determine the most appropriate mechanistic functional model: (1) An ANOVA of proportional mortality as a function of lobster density, and (2) Akaike's information criterion (AIC) to evaluate maximum likelihood results from fitting mechanistic functional response models to the lobster removal data. First, we identified the functional response of recreational divers to spiny lobsters by examining the relationship between the proportional decline in lobster density from before to after the $2 \mathrm{~d}$ mini-season with 1-way ANOVA models, with lobster density as the independent variable. If the relationship between proportional decline and lobster density was not statistically significant, this would indicate density-independent mortality (Type I functional response: Hassell 1978). In cases where proportional lobster removal was density-dependent, a significant reduction in proportional removal at low lobster densities indicated a Type III functional response, whereas a significant increase in proportional removal at low lobster densities indicated a Type II functional response (Lipcius \& Hines 1986, Eggleston et al. 1992, Juliano 2001). In the case of patch heads, variances remained heteroscedastic despite numerous transformations. Therefore, the null hypothesis of no difference in proportional lobster removal with lobster density was assessed using an alpha value below the p-value for rejecting heterogeneous variances (Underwood 1981).

We then fit 3 mechanistic functional response models (Types I, II, and III) using a maximum-likelihood approach to describe the relationship between initial lobster density and the number of lobsters removed from patch reefs and patch heads separately. Models with a large number of parameters are more flexible and will necessarily provide a more accurate description of the data than those with few parameters. In practice, it is not desirable to always accept the most complex model from a candidate set, and it is generally accepted that the best model is one that provides an adequate predictive capability with the fewest parameters (Myung \& Pitt 1997). We chose AIC (Akaike 1973) for model selection, a commonly used approach which provides an objective method for selecting the most parsimonious model that still provides an adequate fit to the data. Based on the outcome of the initial ANOVA analysis of proportional lobster removal $x$ lobster density, and the functional response model generating the lowest AIC value, we then fit the appropriate mechanistic functional response model (Types I, II or III) to describe the best estimates of attack rate $\left(a^{\prime}\right)$ and handling time $\left(T_{\mathrm{h}}\right)$ (Holling 1966, Hassell 1978, Eggleston 1990, Juliano 2001). 


\section{RESULTS}

\section{Habitat-specific impact on lobsters}

Overall, there was a $95.3 \%$ decline in the density of legal-sized spiny lobsters during the $2 \mathrm{~d}$ mini-season on patch reefs and a $79 \%$ decline at patch heads. When we excluded PH4 (Fig. 1), which was located near a protected area and received no observable fishing effort, the percent decline in lobster abundance in patch heads was $90 \%$. The density of legal-sized spiny lobsters at patch reefs and patch heads varied significantly with time but not with location (repeatedmeasures ANOVA; time: both $\mathrm{p}<0.01$, location: both $p>0.20)$. There was no significant time $\times$ location interaction effect for either patch-reef or patch-head habitats (both $\mathrm{p}>0.21$ ). The significant time effect was due to significantly lower lobster densities after the $2 \mathrm{~d}$ fishing season than before it (Fig. 2).
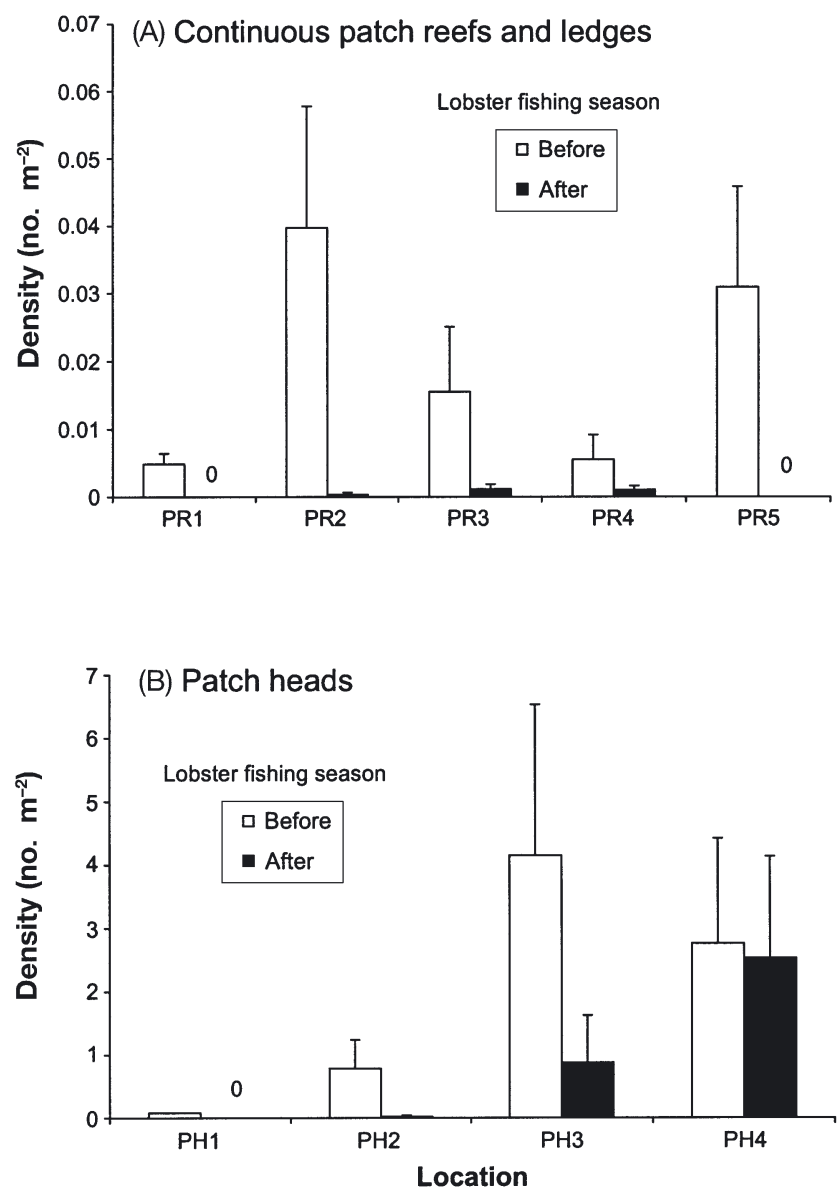

Fig. 2. Panulirus argus. Effects of fishing season (before vs after $2 \mathrm{~d}$ fishing season) and sampling location on mean (+1 SE) lobster (>7 cm CL) density in (A) patch reefs and (B) patch heads. (Note different ordinate scales on this and on subsequent figures)
Fishing effort

During the $2 \mathrm{~d}$ mini-season, we counted an average of 501 boats along the $26 \mathrm{~km}$ continuous reef tract from Content Keys to Jewfish Channel. This count equates to an average density of 9.63 boats $\mathrm{km}^{-2}(\mathrm{SE}=0.02, \mathrm{n}=2)$, which was over 900 times greater than the average density of boats $3 \mathrm{wk}$ after the mini-season during the regular lobster fishing season (mean $=0.01$ boats $\mathrm{km}^{-2}$, $\mathrm{SE}<0.01, \mathrm{n}=3$ ). Fishing effort was $10 \times$ greater on patch heads than patch reefs, and was generally higher during the first than during the second day of the mini-season (Fig. 3). Higher fishing effort on patch heads was probably due to the 100-fold higher lobster densities in patch heads versus patch reefs (Fig. 3). The 1 exception to high effort and fishing mortality on patch heads was PH4, which was located near Little Crane Key, an area that is closed to boaters due to high
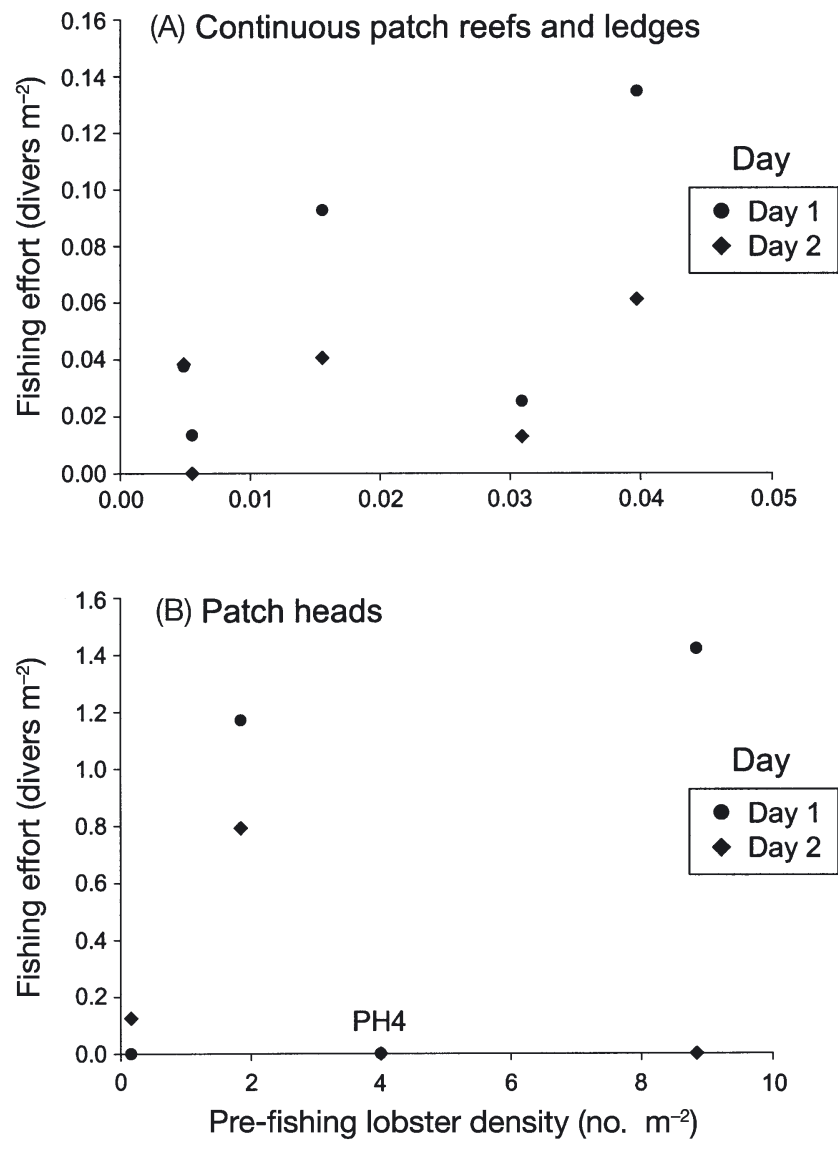

Fig. 3. Panulirus argus. Relationship between fishing effort and density of lobsters (>7 cm CL) immediately prior to the $2 \mathrm{~d}$ fishing season in (A) patch-reef and (B) patch-head habitats. Note that although effort was measured on Days 1 and 2 of the mini-season, lobster density was only measured 1 to $2 \mathrm{~d}$ prior to the mini-season. The fit of linear and non-linear regression models to the data was non-significant for both days combined, as well as effort alone on Day 1 
concentrations of nesting seabirds. There was a positive increase in fishing effort with legal lobster density in both patch reefs and patch heads (Fig. 3); however, the trend was not significant (linear and non-linear regression: both $\mathrm{p}>0.14$ ).

\section{Functional responses of recreational divers}

\section{Patch reefs}

The relationship between the proportion of spiny lobster removed from continuous patch reefs during the mini-season and pre-fishing density was not significant (ANOVA: $F=1.54, \mathrm{df}=4,16, \mathrm{p}=0.25$ ) and therefore
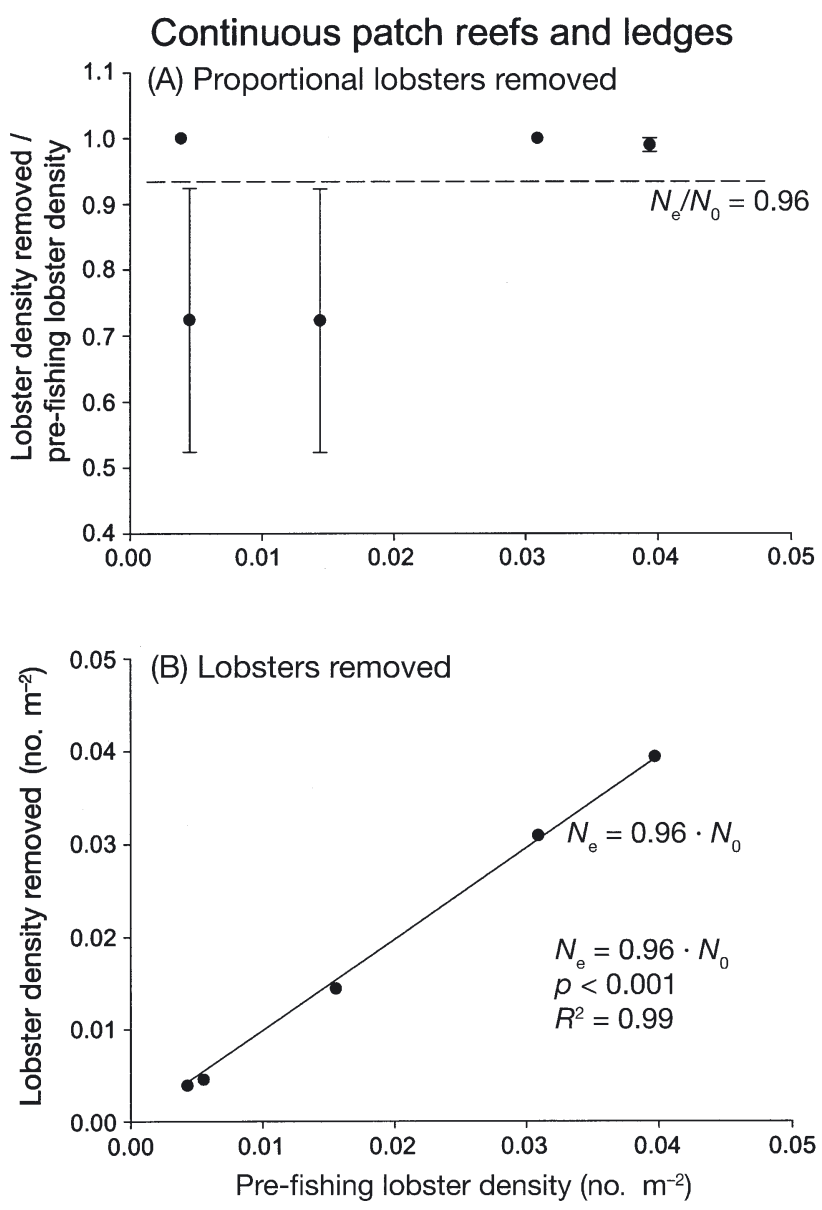

Fig. 4. Functional response of recreational divers to spiny lobsters Panulirua argus (>7 cm CL) in patch reefs. Relationship between (A) mean proportion (SE) of lobster density removed $\left(N_{\mathrm{e}} / N_{0}\right)$ and pre-fishing density $\left(N_{0}\right)$, and (B) mean density of lobsters removed $\left(N_{\mathrm{e}}\right)$ and pre-fishing density $\left(N_{0}\right)$. Densityindependent relationship between $N_{\mathrm{e}} / N_{0}$ and $N_{0}(\mathrm{~A})$ indicates Type I functional response, and justifies fitting mechanistic Type I functional response model to relationship between $N_{\mathrm{e}}$ and $N_{0}$ (B). Hatched line in (A) is average percentage of lobsters removed $(n=5)$. Two data points in (A) contain zero variance density-independent (Fig. 4A), which is indicative of the initial increasing portion of a Type I functional response (Hassell 1978). The relationship between prefishing density and the number of lobsters removed from patch reefs was best described by a mechanistic Type I functional response $(\mathrm{AIC}=2.87$, AIC weight $=$ $0.71)$, compared to Type II $(\mathrm{AIC}=4.87$, AIC weight $=$ 0.25 ) and Type III (AIC $=8.87$, AIC weight $=0.04$ ) Although each model produced nearly identical fits to the data, the Type I functional response described the relationship with the fewest parameters and was favored by the AIC. The relative strength of the support for each functional response was assessed using the ratio of model AIC weights. The Type I model was $\sim 3$ times $(0.71 / 0.25)$ more likely to be the correct model than the Type II functional response, and 20 times more likely than a Type III functional response. Thus, within the range of natural densities measured between Snipe and Content Keys in the GWHNWR, recreational divers display a Type I functional response, and remove a very high and constant proportion $(\sim 95 \%)$ of lobsters.

We estimated the components of diver predation, attack rates $\left(a^{\prime}\right)$ and lobster handling time $\left(T_{\mathrm{h}}\right)$, using mechanistic functional response models to make comparisons of exploitation rates between habitats (patch reefs versus heads), and between lobsters and other recreational fisheries with intense exploitation. By fitting a mechanistic Type I functional response model to the relationship between the number of lobsters removed by divers and lobster density (Fig. 4B), we estimated that the attack rate in patch reefs was 0.021 lobsters $\mathrm{m}^{-2} \mathrm{~h}^{-1}$. Given that lobsters are generally not harvested by divers at night, the true estimates of $a^{\prime}$ are probably twice those of model estimates, which are based on a $48 \mathrm{~h}$ diver 'foraging' period, and are probably closer to 0.04 than 0.02 lobsters $\mathrm{m}^{-2} \mathrm{~h}^{-1}$. At a harvest rate of 0.04 lobsters $\mathrm{m}^{-2} \mathrm{~h}^{-1}$, for example, the patch reef with the highest density (PR2) would, theoretically, be harvested completely in $1 \mathrm{~h}$. This intense harvest rate is probably realistic, especially in habitats where divers were anchored at dawn over areas of high lobster aggregations identified during pre-fishing season reconnaissance, and where these boats apparently reached their limit in less than $1 \mathrm{~h}$ after entering the water (as evidenced by their return to shore: pers. obs.).

\section{Patch heads}

The relationship between the proportion of lobsters removed from patch heads and pre-fishing density was also non-significant and density-independent (ANOVA: $F=3.98, \mathrm{df}=3,13, \mathrm{p}=0.04 ;$ Levene's-test for homogeneity of variances: $\mathrm{p}<0.01$; Fig. $5 \mathrm{~A}$ ). The relation- 

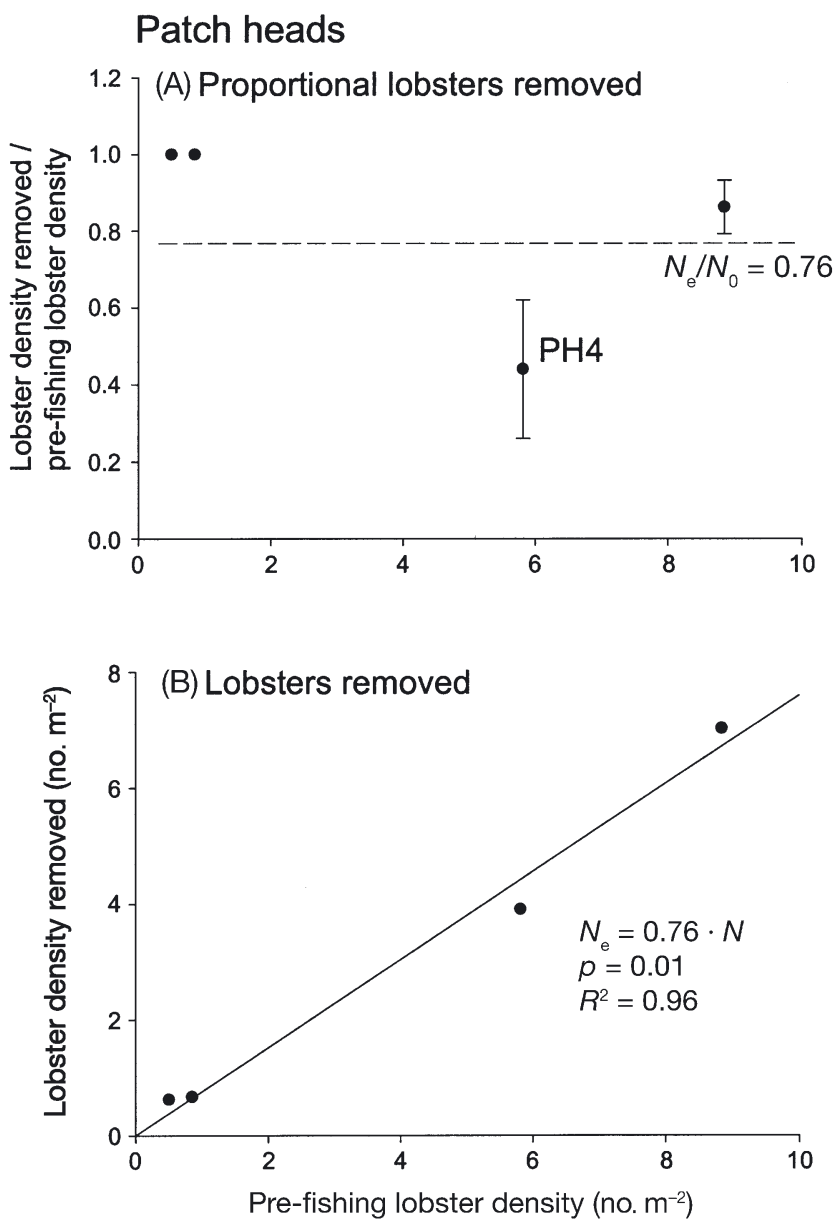

Fig. 5. Panulirus argus. Functional response of recreational divers to spiny lobsters ( $>7 \mathrm{~cm} \mathrm{CL}$ ) in patch heads. Further details as in Fig. 4 legend

ship between pre-fishing density and the number of lobsters removed from patch heads was best described by a mechanistic Type I functional response (AIC = 14.92, AIC weight $=0.71)$ than a Type II $(\mathrm{AIC}=16.92$, AIC weight $=0.25$ ) or Type III (AIC $=20.92$, AIC weight $=0.04)$. The Type I model was $\sim 3 \times(0.71 / 0.25)$ more likely to be the correct model than the Type II functional response and $\sim 20 \times$ more likely than a Type III functional response. A subsequent fit of a mechanistic Type I functional response model (Holling 1966) to the relationship between lobsters removed $\left(N_{\mathrm{e}}\right)$ and prefish lobster densities $\left(N_{0}\right)$ (Fig. 5B) estimated that attack rates were 0.016 lobsters $\mathrm{m}^{-2} \mathrm{~h}^{-1}$. Given that divers only harvest lobsters during the day (as discussed above) $a^{\prime}$ was probably closer to 0.03 than to 0.016 lobsters $\mathrm{m}^{-2} \mathrm{~h}^{-1}$. Handling time was constrained to 0 to successfully fit the lobster-removed data to a Type II functional response model, such that the relationship between $N_{\mathrm{e}}$ and $N_{0}$ was linear and essentially a non-saturated, Type I functional response (Fig. 5B).

\section{DISCUSSION}

The intense removal rates of spiny lobsters by recreational divers measured in this study are among the highest reported rates for marine recreational fishers in the world. For example, fishing effort by recreational divers, as measured by the number of boats observed along the continuous reef tract off the GWHNWR, was approximately 900-fold higher during the $2 \mathrm{~d}$ miniseason than during the 'regular' lobster fishing season. The $2 \mathrm{~d}$ recreational mini-season reduced lobster (>7 cm CL) density by an average of $86 \%$ across patchreef and patch-head habitats in the GWHNWR, with exploitation rates of $\sim 0.03$ to 0.04 lobsters $\mathrm{m}^{-2} \mathrm{~h}^{-1}$ in these habitats. We measured similar rates of exploitation in the nearby Key West National Wildlife Refuge (KWNWR) during July 2000, where lobster densities decreased by $80 \%$ in 2 d (Eggleston \& Dahlgren 2001). The percentage decline in lobster density observed in this and our previous study (Eggleston \& Dahlgren 2001) is higher than that observed for Looe Key, Florida, in 1987, when the abundance of spiny lobster declined by $55 \%$ immediately after the mini-season (Blonder et al. 1992). Similarly, Davis (1977) observed a $58 \%$ decline in spiny lobster abundance after the entire 8 mo fishing season in the sport harvest area of Fort Jefferson National Monument, Dry Tortugas, Florida, a result that prompted the US National Park Service to halt all fishing in National Parks for spiny lobster in 1974. The relatively high exploitation rates measured in the GWHNWR were somewhat surprising, given that this area is located in the 'backcountry' of the Florida Keys, where boat navigation is difficult due to a general lack of navigational aids across numerous shoals, and given that this area is further away from the large population center of Key West compared to the KWNWR (where our previous study was conducted). The relatively large decline in spiny lobster abundance observed in the GWHNWR (this study) and the KWNWR (Eggleston \& Dahlgren 2001) is probably due to the increasing popularity of SCUBA diving and lobster hunting, and detailed knowledge of lobster distribution and abundance patterns due to intense mapping work conducted before the mini-season and the use of technological aids, such as GPS, which allow accurate relocation of prime lobster habitats. Overall, fishing effort was higher in patch-head than patch-reef habitats, probably because patch heads contained 100-fold higher densities of lobsters than patch reefs.

The only other recreational fishery that we are aware of with comparable exploitation rates to those of this and our previous study off Key West (Eggleston \& Dahlgren 2001) is that of fishes in freshwater lakes and streams (Jones 1987, Johnson \& Staggs 1992, Post et al. 2002). For example, individual cutthroat trout 
Salmo clarcki bouvieri in the Yellowstone River in Yellowstone National Park, USA, were caught and released an average of 9.7 times during a $108 \mathrm{~d}$ recreational fishing season, with catch rates averaging $>1$ fish $\mathrm{h}^{-1}$ (Jones 1987). Catch rates of walleye Stizostedion vitreum in Lake Mendota, Wisconsin, averaged 0.061 fish $\mathrm{h}^{-1}$ over a 3 yr period (Johnson \& Staggs 1992). Such high catch rates are apparently not always sustainable. For example, the catch rates for several Canadian recreational fisheries have declined from 5.6 to 0.25 fish $\mathrm{h}^{-1}$ despite a doubling of fishing effort, leading to the collapse of many of these fisheries (Post et al. 2002). Direct comparisons of recreational catch-rates between fishes and spiny lobsters are difficult because, once captured, spiny lobsters are not released as is the case with many species of fishes, and because our catch rates were in units of density/time (no. $\mathrm{m}^{-2} \mathrm{~h}^{-1}$ ), whereas fish catch-rates are typically reported in units of time (fishes $\mathrm{h}^{-1}$ ). The release of fishes after capture coupled with stocking, especially stocked catch-and-release trout fisheries, also help maintain high catch rates.

\section{Application of predator-prey theory}

Given such high exploitation rates of spiny lobsters, how can knowledge of the functional responses of recreational divers be applied to management of the fishery? The most common approach to modeling predation is to assume that the consumption rate per predator is proportional to the abundance of the prey. This linear relationship between predator consumption rates and increasing prey abundance is based on a simple random-search model of predation, assuming that each time a predator detects a prey it instantaneously captures it and begins searching again (Type I functional response). Our data indicated that the number of lobsters removed by divers was directly proportional to lobster density, and that the divers' functional responses did not become saturated at natural levels of lobster density. Thus, in general, recreational divers appear to follow this simple predator-prey model at the levels of lobster density measured in our study. The application of a linear, non-saturated Type I functional response to fisheries management is that lobsters do not attain a relative refuge from divers at low lobster densities, such that removal of lobsters by divers can, and does, lead to local extinction. However, management efforts intended to reduce catch, through decreases in bag limits or the fishing season, would result in a concomitant decrease in exploitation (Fig. 6). Conversely, if lobster densities were relatively high, such that the proportional densities removed by divers were above the minimum level of diver satura-

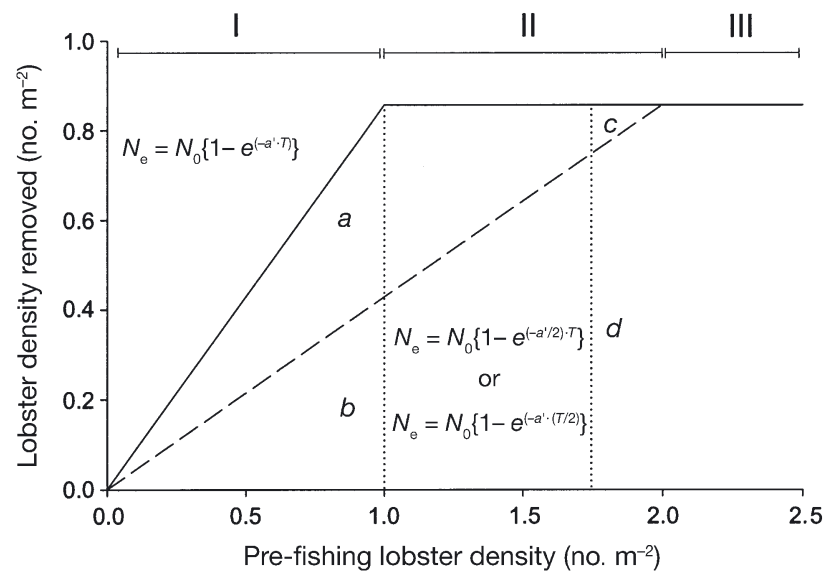

Fig. 6. Schematic of theoretical implications of Type I functional response of recreational divers to fisheries management actions, showing linear relationship (continous line) between lobster density removed $\left(N_{\mathrm{e}}\right)$ and prey fishery density $\left(N_{0}\right)$ that reaches upper asymptote as fishery becomes saturated between Regions I and II. Management actions that reduce the catch by reducing bag limits or fishing season by half (i.e. $a^{\prime} / 2$ and $T / 2$, respectively) will have a proportional reduction (i.e. $a / b=1)$ in catch $\left(N_{\mathrm{e}}\right)$ below saturation (i.e. within Region I), and a decreasing effect (i.e. $c / d \ll 1$ ) on catch rates above saturation (i.e. within Region II). If the fishery were highly saturated (Region III), management actions that reduced fishing effort would have little, if any, effect

tion (e.g. Region III on Fig. 6), management efforts to reduce catch rates would have much less of the desired effect on lobster removal. Also noteworthy was that the observed diver effort was minimal and corresponding lobster removal relatively low at our PH4 site, which was located very close to marker buoys denoting a vessel-exclusion surrounding Little Crane Key, which is protected from boaters due to large colonies of nesting seabirds. Thus, if management desires to reduce per capita recreational fishing pressure on spiny lobsters, establishment of even localized protected areas in patch heads containing high lobster densities should be an extremely effective measure. An important caveat, however, is that our study targeted an area within the GWHNWR that generally receives relatively high fishing effort. A better understanding of the functional responses of recreational divers' to spiny lobsters over a much broader spatial domain and with more variability in fishing effort than measured in this study would provide managers with more accurate information with which to protect intensely exploited lobster stocks.

\section{Conclusions}

What is desperately needed, but rarely attempted, is a theory to predict behavioral responses of fishers to 
management actions (Clark 1985, Post et al. 2002). Recreational fishers are generally considered more complex in their motivations and behavior than commercial fishermen or the type of predators traditionally represented in predator-prey models (Carpenter et al. 1994, Johnson \& Carpenter 1994, Post et al. 2002). Our study indicates the opposite: the catch rates of spiny lobster generally varied linearly with lobster density. Density-independent removal of spiny lobsters by recreational divers contrasts with the general pattern in fisheries, whereby fishing mortality is densitydependent (i.e. depensatory mortality) (Winters \& Wheeler 1985, Crecco \& Overholtz 1990, Hilborn \& Walters 1992). This simple predator-prey response by recreational divers to lobster density should be important to fishery managers because already intense diver-exploitation rates of lobsters are not expected to increase disproportionately at low population densities, which could exacerbate local extinction. Moreover, recreational catch rates should be a reliable indicator of the density of spiny lobster (>7 cm CL) during the $2 \mathrm{~d}$ mini-season, and reductions in fishing effort should have concomitant reductions in catch. Thus, catch rates can be used as lobster-abundance estimators. The recreational diver-lobster predator-prey construct presented in this study provides a useful theoretical framework upon which to build as the spatiotemporal scales of measurements are expanded, management actions are implemented, and the lobster population fluctuates.

Acknowledgements. We thank J. Sobel for facilitating the research funding and his enthusiastic administration of this project, B. Lockwood with the US Fish and Wildlife Service, and N. Klingener with The Oceans Conservancy, for logistical support, Captain L. White for initial field reconnaissance, A. Drew for help in producing the figure of the study site, and J. Hunt for information on the Florida recreational and commercial fishery for Caribbean spiny lobsters. The manuscript benefited from discussions with R. Lipcius. We thank C. Birkeland and 3 anonymous referees for constructive comments on earlier drafts of this paper. Funding for this project was provided by a Challenge Cost-Share Agreement between The Oceans Conservancy and the US Fish and Wildlife Service for Contract 1448-40181-99-6, and NC State University. This research was carried out with a research and education permit from the Florida Keys National Marine Sanctuary Program (FKNMS-2002-061).

\section{LITERATURE CITED}

Abrams P (1982) Functional responses of optimal foragers. Am Nat 120:382-390

Akaike H (1973) Information theory and the extension of the maximum likelihood principle. In: Petrov BN, Caski F (eds) Proceedings of the Second International Symposium on Information Theory. Akademiai Kiado, Budapest, p 267-281

Blonder BI, Hunt JH, Forcucci D, Lyons WG (1992) Effects of recreational and commercial fishing on spiny lobster abundance at Looe Key National Marine Sanctuary. In: Waugh GT, Godwin MH, Kau SM (eds) Proceedings of the 41st Annual Gulf and Caribbean Fisheries Institute Meeting, St. Thomas, U.S.V.I., November, 1988, p 487-491

Butler MJ IV, Herrnkind WF (2000) Puerulus and juvenile ecology. In: Phillips BF, Kittaka J (eds) Spiny lobsters: fisheries and culture, 2nd edn. Fishing News Books, Blackwell Science Publications, Oxford, p 276-301

Carpenter SR, Munoz-Del-Rio A, Newman S, Rasmussen PW, Johnson BM (1994) Interactions of anglers and walleyes in Escanaba Lake, Wisconsin. Ecol Appl 4:822-832

Clark CW (1985) Bioeconomic modeling and fisheries management. John Wiley \& Sons, New York

Cox C, Hunt JH, Lyons WG, Davis G (1997) Nocturnal foraging of the Caribbean spiny lobster (Panulirus argus) on offshore reefs of Florida, USA. Mar Freshw Res 48: 671-679

Crecco V, Overholtz WJ (1990) Causes of density-dependent catchability for Georges Bank haddock Melanogrammus aeglefinus. Can J Fish Aquat Sci 47:385-394

Davis GE (1977) Effects of recreational harvest on a spiny lobster, Panulirus argus, population. Bull Mar Sci 27:223-236

Davis GE, Dodrill JW (1989) Recreational fishery and population dynamics on spiny lobsters, Panulirus argus, in Florida Bay, Everglades National Park, 1977-1980. Bull Mar Sci 44:78-88

Eggleston DB (1990) Behavioural mechanisms underlying variable functional reponses of blue crabs, Callinectes sapidus feeding on juvenile oysters, Crassostrea virginica. J Anim Ecol 59:615-630

Eggleston DB, Dahlgren CP (2001) Distribution and abundance of Caribbean spiny lobsters in the Key West National Wildlife Refuge: relationship to habitat features and impact of an intensive recreational fishery. Mar Freshw Res 52:1567-1576

Eggleston DB, Lipcius RN (1992) Shelter selection by spiny lobster under variable predator risk, social conditions, and shelter size. Ecology 73:992-1011

Eggleston DB, Lipcius RN, Hines AH (1992) Densitydependent predation by blue crabs upon infaunal clam species with contrasting distribution and abundance patterns. Mar Ecol Prog Ser 85:55-68

Eggleston DB, Dahlgren CP, Johnson EG (in press) Fish density, diversity and size-structure within multiple back reef habitats of Key West National Wildlife Refuge, USA. Bull Mar Sci

Florida Fish and Wildlife Conservation Commission (2002) A summary of recreational spiny lobster landings and effort in Florida. Florida Marine Research Institute, Marathon, FL

Forcucci DF, Butler MJ IV, Hunt JH (1994) Growth and population dynamics of juvenile spiny lobsters, Panulirus argus, in Florida Bay. Bull Mar Sci 54:805-818

Haaker PL, Davis GE, Taniguchi IJ (1996) Serial depletion in marine invertebrate diving fisheries. J Shellfish Res 15: 526

Hassell MP (1978) The dynamics of arthropod predator-prey systems. Monogr Popul Biol 13

Hilborn R, Walters CJ (1992) Quantitative fisheries stock assessment. Chapman \& Hall, New York

Holling CS (1966) The functional response of invertebrate predators to prey density. Mem Entomol Soc Can 48:1-87

Hunt JH (2000) Status of the fishery for Panulirus argus in Florida. In: Phillips BF, Kittaka J (eds) Spiny lobsters: fisheries and culture, 2nd edn. Fishing News Books, Blackwell Science Publications, Oxford, p 189-199

Hunt JH, Lyons WG, Kennedy FS Jr (1986) Effects of exposure 
and confinement on spiny lobsters, Panulirus argus, used as attractants in the Florida trap fishery. Fish Bull US 84: $69-76$

Huntley ME (1981) Non-selective, non-saturated feeding by three calanoid copepod species in the Labrador Sea. Limnol Oceanogr 26:834-843

Johnson BM, Carpenter SR (1994) Functional and numerical responses: a framework for fish-angler interactions? Ecol Appl 4:808-821

Johnson BM, Staggs MD (1992) The fishery. In: Kitchell JF (ed) Food web management: a case study of Lake Mendota. Springer-Verlag, New York, p 353-375

Jones RD (1987) The Yellowstone experience: a decade of catch-and-release. In: Catch-and-release fishing, a decade of experience. Proceedings of a National Sport Fishing Symposium, Humbolt State University, Arcata, California, p 94-99

Juliano SA (2001) Nonlinear curve fitting: predation and functional response curves. In: Scheiner SM, Gurevitch J (eds) Design and analysis of ecological experiments. Oxford University Press, New York, p 178-196

Kitchell JF (ed) (1992) Food web management: a case study of Lake Mendota. Springer-Verlag, New York

Kitchell JF, Carpenter SR (1993) Variability in lake ecosystems: complex responses by the apical predator. In: McDonnell MJ, Pickett STA (eds) Humans as components of ecosystems. Springer-Verlag, New York, p 111-124

Labisky RF, Gregory DR, Conti JA (1980) Florida's spiny lobster fishery: an historical perspective. Fisheries 5:28-36

Leeworthy VR (2002) Economic impact of the recreational lobster fishery on Monroe County, 2001. National Ocean Service, Silver Spring, MD

Lipcius RN, Hines AH (1986) Variable functional responses of a marine predator in dissimilar homogeneous microhabitats. Ecology 67:1361-1371

Lyons WG (1986) Problem and perspective regarding recruit-

Editorial responsibility: Otto Kinne (Editor),

Oldendorf/Luhe, Germany ment of spiny lobster, Panulirus argus, to the south Florida fishery. Can J Fish Aquat Sci 43:2099-2106

Lyons WG, Barber DG, Foster SM, Kennedy FS, Milano GR (1981) The spiny lobster, Panulirus argus, in the middle and upper Florida Keys: population structure, seasonal dynamics, and reproduction. Fla Mar Res Publ 38:1-38

Magnuson JJ (1991) Fish and fisheries ecology. Ecol Appl 1: $13-26$

Murdoch WW, Bence JR (1987) General predators and unstable prey populations. In: Kerfoot W, Sih A (eds) Predation: direct and indirect impacts on aquatic communities. University Press of New England, Hanover, NH, p 17-31

Myung IJ, Pitt MA (1997) Applying Occam's razor in modeling cognition: a Bayesian approach. Psychol Bull Rev 4: 79-95

Post JR, Sullivan M, Cox S, Lester NP and 5 others (2002) Canada's recreational fisheries: the invisible collapse? Fisheries 27:5-16

Powers JE, Sutherland DL (1989) Spiny lobster assessment, CPUE, size frequency, yield per recruit, and escape gap analysis. NOAA Tech Rep NMFS SFC/CRD-88/89-24

Seitz RD, Lipcius RN, Hines AH, Eggleston DB (2001) Density-dependent predation, habitat variation, and the persistence of marine bivalve prey. Ecology 82:2435-2451

Silberman JD, Sarver SK, Walsh PJ (1994) Mitochondrial DNA variation and population structure in the spiny lobster Panulirus argus. Mar Biol 120:601-608

Underwood AJ (1981) Techniques of analysis of variance in experimental marine biology and ecology. Oceanogr Mar Biol Annu Rev 19:513-605

Vaughan DS, Carmichael JT (2000) Assessment of Atlantic red drum for 1999: northern and southern regions. NOAA Techn Memo NMFS SEFSC-447

Winters GH, JP Wheeler (1985) Interaction between stock area, stock abundance and catchability coefficient. Can J Fish Aquat Sci 42:989-998

Submitted: January 9, 2003; Accepted: May 6, 2003 Proofs received from author(s): July 15, 2003 